\title{
Rancang Bangun Aplikasi Bantu Hafal Al-Qur'an Metode At-Taisir Berbasis Android
}

\author{
(Design and Develop an Android Application of At-Taisir Method for Al-Qur'an \\ Memorizing)
}

\author{
Nurul Hidayah*, Royana Afwani \\ Dept Informatics Engineering, Mataram University \\ J1. Majapahit 62, Mataram, Lombok NTB, INDONESIA \\ Email: nurulhi948@gmail.com, [royana, andy]@unram.ac.id
}

*Penulis korespondensi

\begin{abstract}
Currently, the activity of memorizing the Qur'an with the At-Taisir method initiated by Adi Hidayat is still done manually. This study aims to display the At-Taisir method which was previously still in manual form into a mobile application using Android technology with native application types. This is expected to make the process of memorizing using the At-Taisir method easier to do without having to wait to get the At-Taisir manuscript first. The AtTaisir application has a flexible appearance where if one day you want to make the application load $30 \mathrm{juz} \mathrm{Al}-\mathrm{Qur}$ 'an then all you need to add is only the database, while the appearance can be changed or not changed at all. Based on the results of the tests carried out the percentage of success of the At-Taisir application reached $85.9 \%$.
\end{abstract}

Key words: Qur'an, Memorizing, At-Taisir Method, Android, Native.

\section{PEndahuluan}

Menghafal Al-Qur'an dapat menggunakan beberapa metode yang bisa disesuaikan dengan kebutuhan tiap individu salah satunya yaitu metode At-Taisir. Metode ini resmi dipublikasikan pada kajian Hari Al-Qur'an tanggal 28 Januari 2018 di Masjid Istiqlal Jakarta setelah sebelumnya dilakukan uji coba untuk diterapkan pada kedua Hafidz Indonesia 2017 Kamil dan Ahmad. Metode At-Taisir digagas oleh ustadz Adi Hidayat dimana metode ini menerapkan proses menghafal Al-Qur'an disertai mendalami denah mushaf Al-Qur'an. Metode At-Taisir ini membuat seorang penghafal Al-Qur'an menjadi lebih mudah mengingat posisi hafalan yang dihafalkan secara terperinci di halaman berapa, baris ke berapa, halaman sebelah kiri atau kanan. Selain itu, metode At-Taisir ini sangat menekankan penghafal agar teratur dalam menghafal dan penghafal sudah belajar tahsin terlebih dahulu sebelum mulai menghafal Al-Qur'an. Hal tersebut menjadi daya tarik bagi masyarakat terhadap metode ini sehingga pada saat launching buku dan mushaf-nya, peserta yang hadir sebanyak 200.000 orang dari berbagai wilayah dan kalangan. Selain itu dalam kurun waktu satu hari telah habis 9.000 eksemplar cetakan pertama baik buku maupun mushaf At-Taisir[1].

Proses menghafal dengan metode At-Taisir saat ini masih manual. Penghafal harus menyediakan audio, catatan hafalan dan mushaf At-Taisir yang disediakan oleh Institut Quantum Akhyar ketika akan menghafal. Mushaf At-Taisir tidak diperjualbelikan tetapi dibagikan secara gratis kepada masyarakat. Peluang untuk mendapatkan mushaf At-Taisir tidak dapat diprediksi sebab pihak Institut Quantum Akhyar mencetak mushaf secara terbatas dengan waktu yang tidak menentu.

Berdasarkan uraian tersebut penulis membangun sebuah aplikasi yang memberikan kemudahan dalam menghafal Al-Qur'an sebagai tugas akhir dengan judul "Rancang Bangun Aplikasi Bantu Hafal Al-Qur'an Metode At-Taisir Berbasis Android”. Adanya aplikasi ini diharapkan dapat menjadi media bantu aktivitas menghafal Al-Qur'an menggunakan metode At-Taisir.

\section{TINJAUAN PUSTAKA}

Penelitian yang dilakukan oleh Danu Wijaya menjelaskan bagaimana merancang dan membangun sebuah aplikasi muroja'ah Al-Qur'an untuk mengingat hafalan bacaan Al-Qur'an menggunakan teknologi android, SQLite dan harus online. Sistem ini menghasilkan aplikasi yang memiliki kartu murojaah per halaman yang berisi potongan awal ayat pada satu halaman Al-Qur'an. Metode menghafal yang diterapkan masih per ayat dan bebas memilih ayat yang ingin dihafalkan. Data yang digunakan mencakup data teks latin Al-Qur'an 30 juz, data animasi gambar format GIF, dan data format suara mp3. Selain itu, penghafal tidak dituntut memiliki pendamping selama proses menghafal dan aktivitas menghafal tidak ditentukan secara spesifik[2].

Penelitian yang dilakukan oleh Irawan dan Yanyan membangun aplikasi bantu menghafal Al-Qur'an dengan arsitektur fisik sistem terdiri dari dua komponen utama yaitu aplikasi frontend dan dropbox. Pada sistem ini, aplikasi fronted merupakan komponen yang aktif, sedangkan dropbox bertindak sebagai penyimpan data animasi gambar dan data suara. Sistem ini menyediakan fitur catatan hafalan surat dan ayat Al-Qur'an yang telah dihafal dan menyediakan layanan suara yang ditampilkan secara berulang-ulang. Karena hafalan ditampilkan dalam bentuk animasi GIF per ayat sehingga metode menghafal 
yang digunakan juga masih per ayat. Data yang digunakan meliputi data Al-Qur'an 30 juz dan data suara format mp3. Adapun kekurangan dari sistem ini adalah penghafal tidak dituntut memiliki pendamping selama proses menghafal dan aktivitas menghafal tidak ditentukan secara spesifik[3].

Penelitian yang dilakukan oleh Lutfi Lubis menitik beratkan menghafal menggunakan metode mendengar sehingga luaran yang dihasilkan berupa sebuah aplikasi pengulangan ayat Al-Qur'an dalam menghafal. Seluruh audio Al-Qur'an tersimpan secara online dan ketika akan memutar ayat untuk pertama kali, file harus diunduh terlebih dahulu. Audio yang pernah diputar akan tersimpan di memory smartphone. Fitur yang dikembangkan pada sistem ini adalah opsi pemutaran ayat, perencanaan hafalan dan manajemen hafalan. Sistem ini juga memberikan alternatif kepada pengguna untuk memilih Qori yang diinginkan. Adapun kekurangan dari sistem ini adalah pengguna harus online terlebih dahulu untuk dapat menggunakan aplikasi tersebut[4].

Berdasarkan tinjauan pustaka tersebut dan refrensi yang penulis baca, belum ada aplikasi yang menggunakan metode At-Taisir dalam merancang dan membangun aplikasi bantu hafal Al-Qurán. Pada penelitian sebelumnya user bebas menentukan waktu menghafal dan bebas memilih ayat atau surat yang ingin dihafalkan sesuai keinginan. Namun pada penelitian saat ini, peneliti mencoba menyajikan kondisi yang berbeda dimana ayat Al-Qur'an yang akan dihafalkan yaitu per halaman dan ditentukan sesuai metode At-Taisir. Selain itu pada penelitian yang akan dilakukan hanya akan menggunakan juz satu Al-Qur'an saja sebagai bahan uji coba sedangkan pada beberapa refrensi yang ada rata-rata menggunakan 30 juz Al-Qur'an atau juz 30 Al-Qur'an. Oleh karena itu penulis akan mengkombinasikan hasil penelitian sebelumnya untuk membangun aplikasi bantu hafal AlQur'an menggunakan metode At-Taisir berbasis Android.

Secara umum metode menghafal Al-Qur'an dibagi menjadi tiga bagian. Metode pertama dinamakan metode keseluruhan dimana penghafal membaca satu halaman dari baris pertama hingga baris terakhir sampai hafal sempurna. Metode kedua disebut metode bagian dimana penghafal membaca ayat per ayat sampai hafal kemudian dilanjutkan membaca ayat berikutnya. Sedangkan metode ketiga merupakan gabungan dari metode pertama dan kedua, dimana penghafal terlebih dahulu menghafal satu halaman penuh kemudian mengulang-ulang menghafal beberapa bagian ayat untuk menguatkan hafalan [5]. Metode AtTaisir yang merupakan metode pendekatan terbaru dalam menghafal Al-Qur'an dimana pada kasus diatas metode At-Taisir menggunakan metode campuran dalam proses menghafalnya.

Metode At-Taisir tidak hanya sekedar membuat seseorang menghafal Al-Qur'an saja tetapi juga mendalami denah mushaf Al-Qur'an [6]. Mushaf At-Taisir yang menjadi alat bantu menghafal menggunakan metode At-Taisir memiliki tiga bagian utama yaitu tulisan ayat berbahasa arab, terjemahan, dan kolom muraja'ah [6].
Contoh desain mushaf At-Taisir dapat dilihat pada Gambar 1 dan Gambar 2.

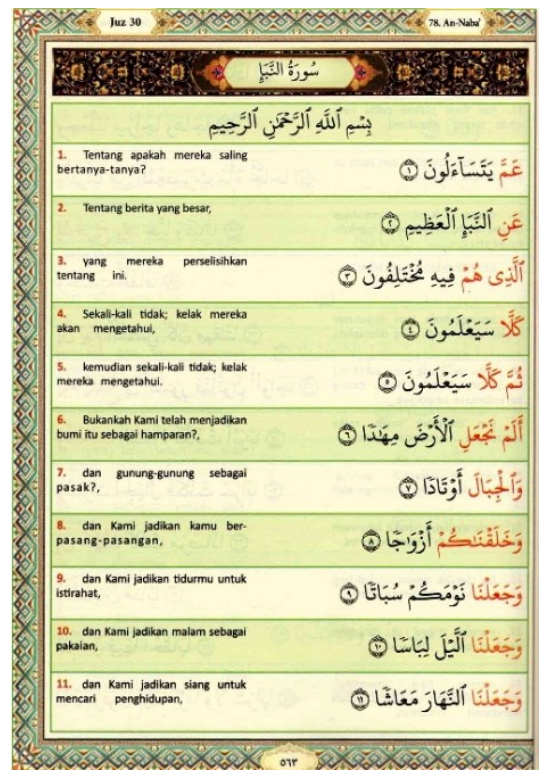

Gambar. 1. Ayat dan terjemahan mushaf At-Taisir.

Desain kolom murajaah seperti yang ditunjukkan pada Gambar 2 membagi mushaf menjadi dua bagian yaitu bagian kiri dan bagian kanan. Bagian kiri akan berisi seluruh potongan awal ayat yang berada di halaman kiri dalam Al-Qur'an, begitu juga dengan bagian kanan. Posisi kiri dan kanan ini mengikuti posisi halaman dalam AlQur'an pojok standar.

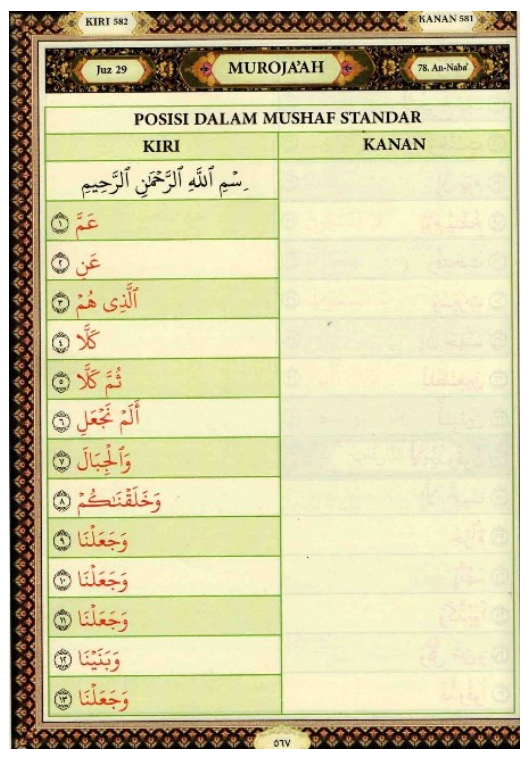

Gambar. 2. Kolom muraja'ah mushaf At-Taisir.

Android sendiri merupakan sebuah teknologi yang sering dimanfaatkan dalam pembuatan aplikasi bergerak (mobile), berbasis linux dan menyediakan platform terbuka bagi para pengembang[7]. 


\section{Metode Penelitian}

Metode pengembangan yang digunakan untuk merancang dan membangun aplikasi bantu hafal AlQur'an metode At-Taisir ini adalah metode water fall yang ditunjukkan pada Gambar 3.

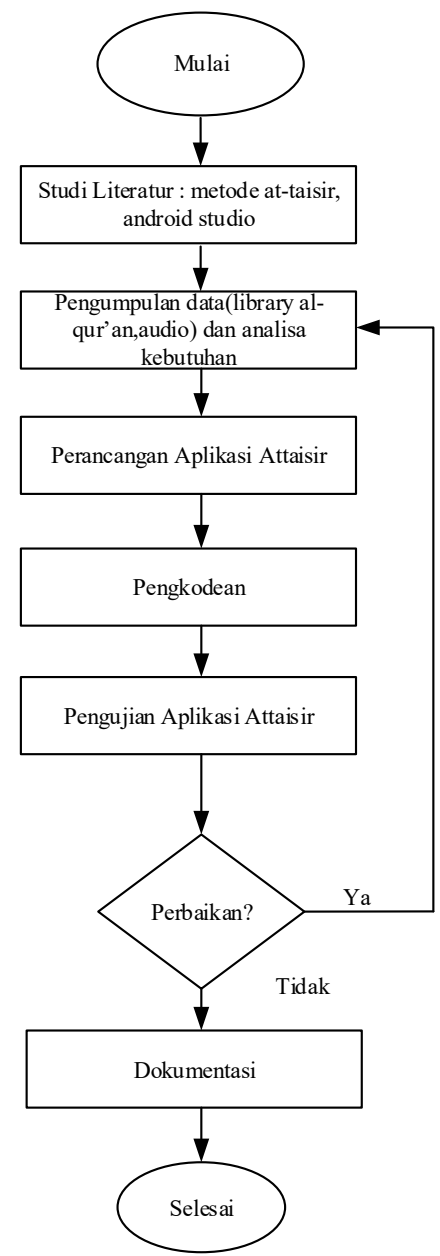

Gambar. 3. Metode pengembangan aplikasi At-Taisir.

\section{A. Studi Literatur}

Langkah awal yang dilakukan adalah mengumpulkan bahan sebagai studi literatur untuk membuat aplikasi media bantu hafal juz satu Al-Qur'an ini. Studi literatur yang dilakukan diantaranya mengenai konsep bagaimana menghafal menggunakan metode At-Taisir. Pembelajaran tentang metode tersebut dilakukan dengan memahami dari buku dan observasi (mencoba) langsung metode At-Taisir dalam menghafal. Selain itu juga penulis melakukan studi literatur yang berhubungan dengan pemrograman atau digitalisasi Al-Qur'an dan pembuatan aplikasi At-Taisir ini secara umum.

\section{B. Pengumpulan Data dan Analisa Kebutuhan}

Tahap pertama yang dilakukan yaitu pengumpulan data. Pengumpulan data yang penulis lakukan melalui dua hal yaitu wawancara dan mengumpulkan library AlQur'an. Wawancara dilakukan untuk mengetahui seperti apa minat masyarakat terhadap metode At-Taisir dan respon penghafal Al-Qur'an terkait metode At-Taisir jika disajikan dalam bentuk aplikasi android. Setelah itu penulis mengumpulkan library data teks dan audio Al-Qur'an yang tersedia untuk diseleksi yang sesuai dengan kebutuhan. Database teks Al-Qur'an penulis ambil dari situs resmi tanzil.net yang kemudian diolah agar sesuai dengan mushaf At-Taisir yang menjadi acuan dalam metode At-Taisir. Mushaf At-Taisir tersebut diterbitkan oleh Institut Quantum Akhyar yang penulis dapatkan secara gratis saat kegiatan Islamic Book Fair 2018.

Berdasarkan studi literatur dan pengumpulan data yang telah dilakukan, penulis melakukan analisis kebutuhan sehingga secara umum kebutuhan fungsional yang perlu ada di dalam aplikasi Attaisir ini adalah sebagai berikut:

1. Aplikasi menampilkan halaman menghafal yang berisi data Al-Qur'an dan terjemahan per halaman sesuai AlQur'an pojok standar.

2. Aplikasi menampilkan halaman murajaah yang berisi awal kata tiap ayat Al-Qur'an dan sekaligus posisinya di dalam Al-Qur'an pojok standar.

3. Terdapat fitur "status hafalan" yang akan dijadikan refrensi sudah sampai mana halaman Al-Qur'an yang dihafalkan.

4. Terdapat fitur "predikat" untuk mengetahui kualitas hafalan yang dihafalkan oleh penghafal.

\section{Perancangan Aplikasi At-Taisir}

Pembangunan aplikasi At-Taisir ini menggunakan Android Studio versi 3.3.0 dan SDK 28. Tahap perancangan merupakan tahapan penggambaran aplikasi Attasir yang akan dibangun. Terdapat lima perancangan yang dilakukan pada tahap ini, yaitu perancangan arsitektur aplikasi, perancangan database aplikasi dalam bentuk $E R$ Diagram, perancangan dalam bentuk $U M L$, dan perancangan dalam bentuk interface.

\section{C.1. Perancangan Arsitektur Aplikasi}

Aplikasi At-Taisir dibuat dalam bentuk native dan offline, dimana database yang akan digunakan berada satu paket di dalam aplikasi sehingga penghafal tidak perlu online terlebih dahulu untuk dapat menggunakan aplikasi.

\section{C.2. Perancangan Database Aplikasi}

Perancangan database pada aplikasi ini memiliki dua tahap yang pertama adalah perancangan Entity Relationship Diagram (ERD) dan perancangan struktur tabel. Pada perancangan ERD, aplikasi ini dirancang memiliki tiga entitas yaitu entitas quran_text, entitas status_hafalan dan entitas predikat. Ketiga entitas tersebut akan dibuat menjadi tiga tabel yang tersimpan dalam satu database bernama taisir pada $M y S Q L$.

\section{C.3. Perancangan UML Aplikasi}

Perancangan $U M L$ pada aplikasi At-Taisir ini terdiri dari perancangan Use case diagram, Class diagram, Sequence diagram dan Activity diagram. Perancangan use case diagram aplikasi At-Taisir dapat dilihat pada Gambar. 4. Use case menggambarkan proses interaksi 
antara actor atau pengguna dengan aplikasi [8]. Proses interaksi antara pengguna dengan aplikasi At-Taisir antara lain dapat melihat menu Petunjuk, melakukan aktivitas Menghafal dan Murajaah, serta mengakses menu About. Setiap halaman Al-Qur'an yang terdapat dalam menu menghafal terdapat status hafalan begitu juga pada menu murajaah terdapat predikat hafalan.

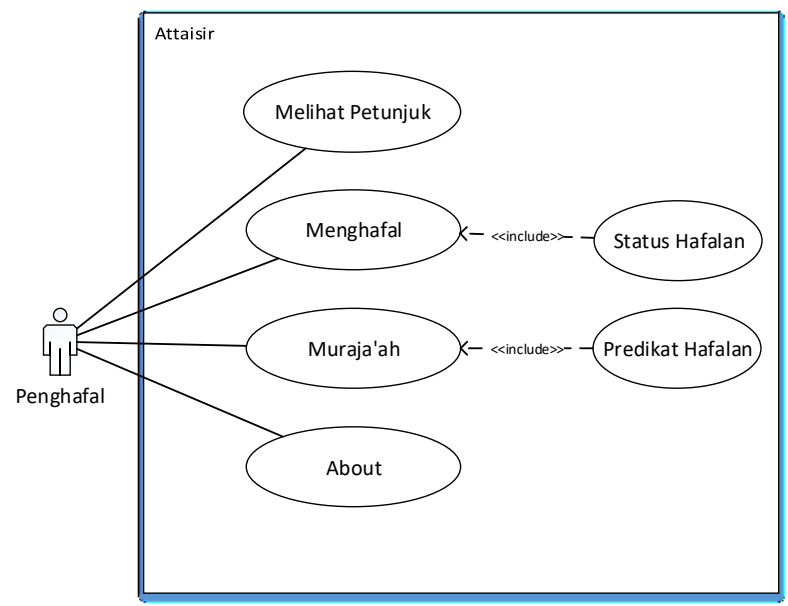

Gambar. 4. Use case diagram aplikasi At-Taisir.

Selain use case diagram juga terdapat beberapa sequence diagram. Gambar 5 menunjukkan sequence diagram petunjuk. Pengguna mengakses MainMenu lalu memilih menu petunjuk kemudian setelah itu akan tampil isi dari menu petunjuk

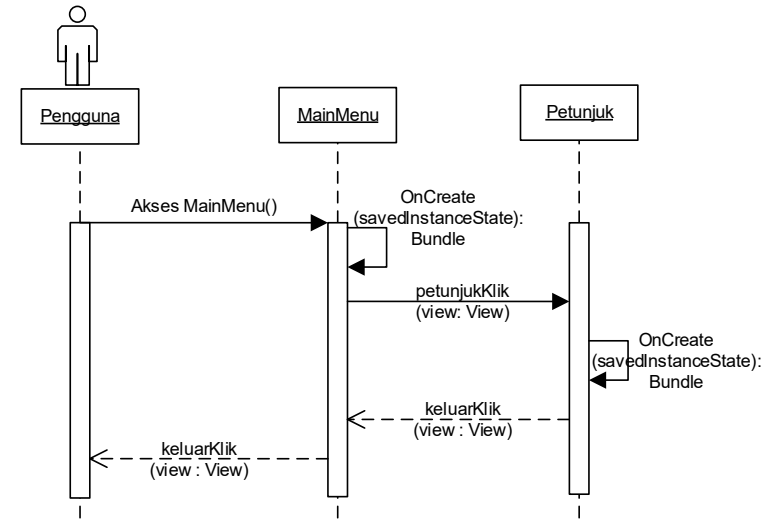

Gambar. 5. Sequence diagram Petunjuk.

Sequence diagram Menghafal ditampilkan pada Gambar 6. Pengguna mengakses MainMenu lalu memilih menu menghafal, semua database yang ada pada menu menghafal kemudian diambil dari database dan ditampilkan pada menu menghafal. Database tersebut berupa teks Qur'an, audio dan status hafalan..

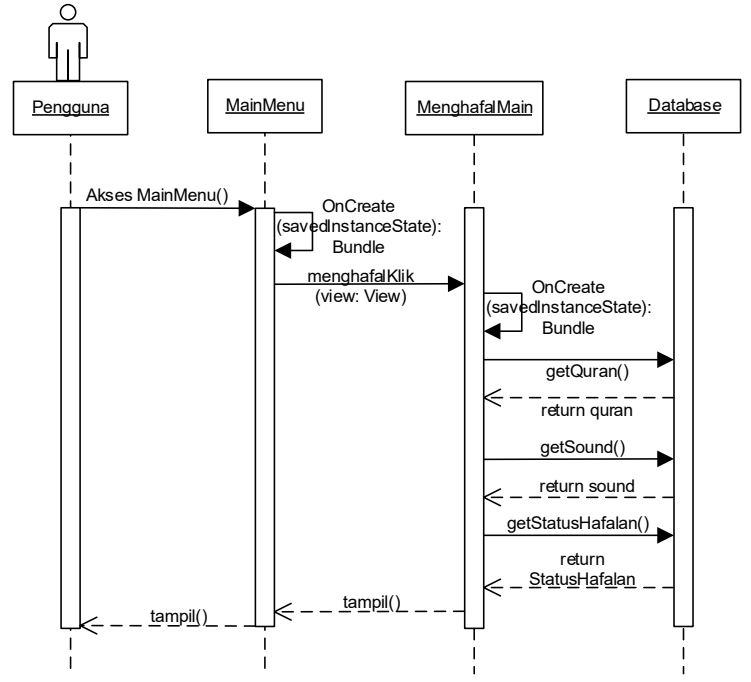

Gambar. 6. Sequence diagram Menghafal.

Sequence diagram Murajaah ditampilkan pada Gambar 7. Sequence diagram tersebut menjelaskan proses menu murajaah. Penghafal mengakses MainMenu lalu memilih menu murajaah dan database murajaah berupa side diambil kemudian ditampilkan. Pada halaman murajaah penghafal memilih predikat, lalu database predikat diambil dan ditampilkan pada menu murajaah.

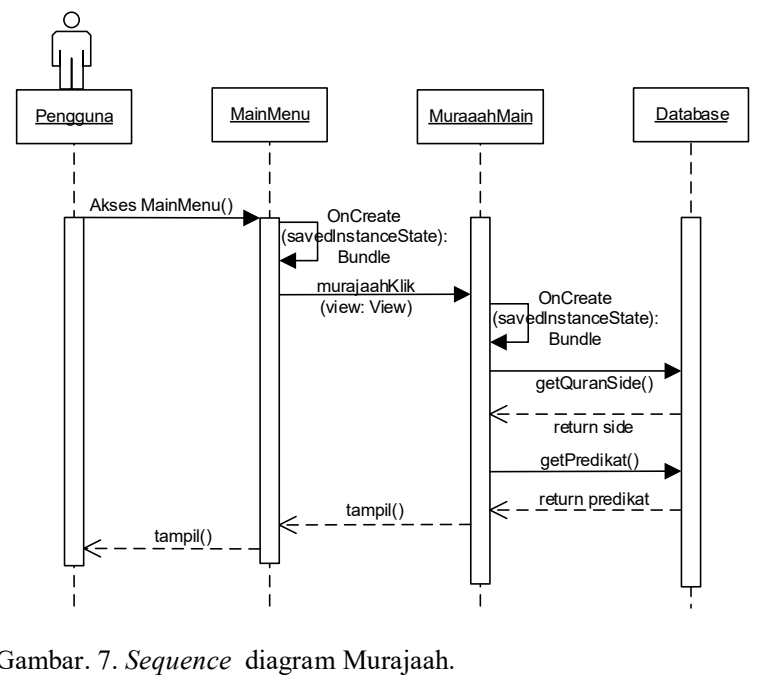

Sequence diagram About ditampilkan pada Gambar 8. Pengguna mengakses MainMenu lalu memilih menu About kemudian setelah itu akan tampil isi dari menu about. 


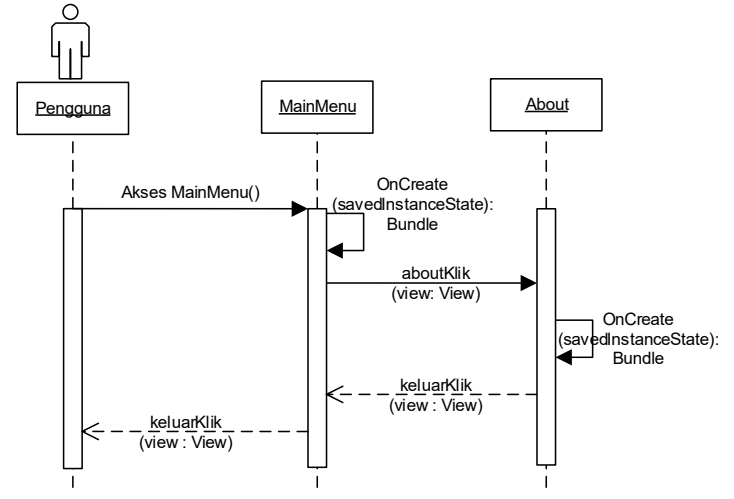

Gambar. 8. Sequence diagram About.

\section{C.4. Perancangan Interface Aplikasi}

Rancangan user interface pada aplikasi At-Taisir terbagi menjadi beberapa bagian sesuai dengan kebutuhan aplikasi yaitu Halaman Utama, Halaman Petunjuk, Halaman Menghafal, Halaman Al-Qur'an, Halaman Murajaah, dan Halaman About.

\section{Pengkodean}

Tahapan selanjutnya adalah proses implementasi rancangan sistem yang sudah dilakukan ke dalam bentuk bahasa pemrograman (coding). Pada pembuatan aplikasi media bantu hafal Al-Qur'an metode At-Taisir ini penulis menggunakan bahasa pemrograman java dengan tools Android Studio.

\section{E. Pengujian Aplikasi At-Taisir}

Pengujian yang dilakukan untuk menguji aplikasi AtTaisir ini ada dua yaitu pengujian black box dan pengujian kuesioner Mean Opinion Score (MOS). Pengujian dengan metode black box digunkan untuk melihat keseluruhan fungsi-fungsi yang telah selesai dan membandingkan dengan rancangan yang telah dibuat sebelumnya. Pengujian aplikasi dengan kuesioner melibatkan responden untuk memberikan penilaian subjektif dengan metode MOS. Responden untuk pengujian aplikasi ini yaitu 35 orang yang terdiri dari masyarakat umum yang belum menghafal dan sedang menghafal Al-Qur'an. Tahap pengujian ini berguna untuk mengetahui kualitas dan keberhasilan aplikasi yang telah dibuat[9].

\section{F. Dokumentasi}

Tahap dokumentasi ini dilakukan pengambilan bukti bahwa peneliti telah melakukan pengujian dari aplikasi media bantu hafal Al-Qur'an metode At-Taisir berupa dokumentasi pada saat melakukan pengujian dan menyimpan hasil jawaban responden sebagai bentuk dokumentasi pengujian dengan kuesioner. Sistem yang telah berfungsi dengan baik dan sesuai dengan rancangan yang ada akan didokumentasikan dalam bentuk laporan

\section{HASIL DAN PEMBAHASAN}

Terdapat beberapa hal yang perlu dijelaskan terkait implementasi rancangan aplikasi At-Taisir yang sudah dijabarkan pada bahasan bab sebelumnya. Hal tersebut meliputi implementasi project aplikasi, implementasi database, implementasi tampilan aplikasi, hasil pengujian aplikasi dengan black box dan hasil pengujian aplikasi dengan Mean Opinion Score (MOS).

\section{A. Implementasi Project Aplikasi}

Pembuatan aplikasi At-Taisir berbasis android memiliki struktur project dengan empat folder utama yaitu manifests, java, assets dan folder res.

\section{B. Implementasi Database Aplikasi}

Database teks Al-Qur'an yang sudah diambil dari situs tanzil akan diolah secara bertahap. Pihak tanzil menyediakan database teks Al-Qur'an dengan berbagai pilihan, untuk kasus aplikasi At-Taisir pilihan teks Qur'an yang diambil adalah jenis simple enhanced dengan format $S Q L$. Database yang disediakan oleh tanzil hanya memiliki atribut index, sura, aya dan teks. Sehingga untuk memenuhi kebutuhan aplikasi At-Taisir yang akan dibangun peneliti harus menambahkan beberapa atribut tambahan yaitu awal_aya, halaman, terjemahan, audio dan posisi. Struktur database-nya dapat dilihat pada Gambar 9. Gambar. 9. Struktur Database

Atribut awal_aya dibuat sebagai kata kunci yang akan ditampilkan pada halaman murajaah. Potongan awal ayat

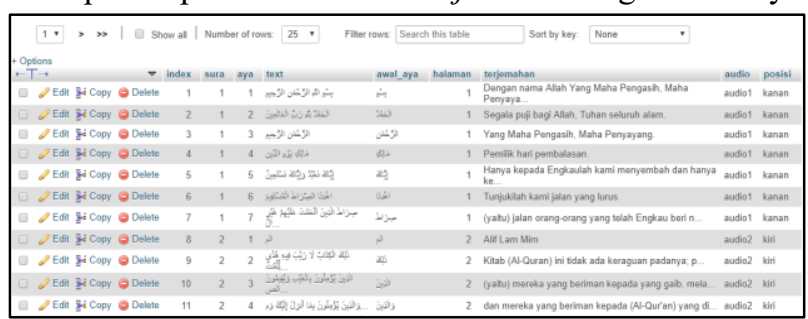

ini di salin dari teks ayat Al-Qur'an kemudian ditempel pada atribut awal_aya. Atribut halaman berguna untuk menentukan letak tiap ayat Al-Qur'an berada dihalaman berapa. Selama mengisi atribut halaman, penulis harus melihat Al-Qur'an pojok standar agar tidak salah dalam menentukan halaman. Jumlah total halaman yang digunakan pada aplikasi ini ada 30 halaman yang terdiri dari juz 1 (dari halaman 1-21) dan sebagian juz 2 (dari halaman 22-30). Sedangkan total keseluruhan ayat AlQur'an yang digunakan sebanyak 196 ayat.

Atribut terjemahan digunakan untuk menampilkan terjemahan Al-Qur'an dan penulis berpatokan pada terjemahan yang dikeluarkan oleh kemenag dalam mengisi atribut terjemahan pada database. Atribut audio digunakan sebagai penyimpanan data audio yang sudah ada pada file raw. Atribut posisi berfungsi sebagai penentu posisi tiap ayat Al-Qur'an apakah terletak diposisi sebelah kiri atau sebelah kanan dalam Al-Qur'an. Posisi ini menjadi salah satu hal yang penting dalam metode At-Taisir. Atribut status_hafalan digunakan untuk menyimpan nilai status hafalan pada halaman menghafal. Atribut predikat yang berfungsi untuk menyimpan nilai predikat pada halaman murajaah. Ketika semua database sudah dibuat dan dilengkapi di mysql maka proses selanjutnya yaitu 
database dalam bentuk $M y S Q L$ ini akan dikonversi menjadi SQLite pada situs rebasedata.

\section{Implementasi Tampilan Aplikasi}

Tampilan aplikasi At-Taisir terbagi menjadi 7 bagian yaitu Halaman Utama, Menu Petunjuk, Menu Menghafal, Halaman Al-Qur'an, Menu Murajaah, Halaman Murajaah, dan Menu About.

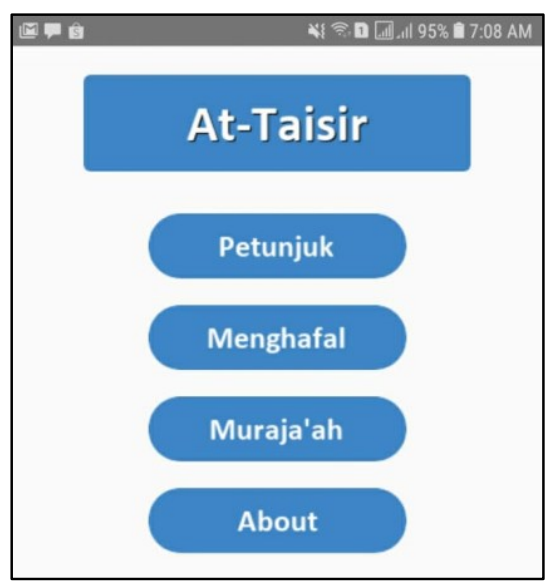

Gambar. 10. Halaman Utama

Halaman utama ini merupakan halaman yang pertama kali muncul ketika pengguna mengoperasikan aplikasi AtTaisir. Halaman utama berisi empat menu seperti yang terlihat pada Gambar 10 yaitu menu Petunjuk, menu Menghafal, menu Muraja'ah, dan menu About..

\begin{tabular}{l} 
Petunjuk Menghafal Dengan Metode \\
At-Taisir \\
Aplikasi ini direkomendasikan bagi Anda yang \\
mengejar target menghafal Al-Qur'an 1 hari 1 halaman. \\
Pastikan Anda sudah belajar tahsin (memperbaiki \\
bacaan) Al-Qur'an sebelum mulai menghafal. \\
Pilihlah satu guru yang berkompeten untuk \\
mendampingi Anda selama proses menghafal. \\
Aktivitas menghafal dapat dilakukan pada waktu \\
terbaik menurut Al-Qur'an yaitu pada pukul 03.00 s/d \\
06.00 WITA. \\
Aktivtas murajaah (mengulang) hafalan dilakukan \\
setiap sholat Sunnah Qobliyah-Ba'diyah dan sebelum \\
tidur. \\
Pilih "status hafalan" pada halaman menghafal setiap \\
Anda sudah selesai menghafal satu halaman Al-Qur'an. \\
Mintalah guru Anda memberikan "predikat" hafalan \\
pada halaman murajaah setiap kali Anda selesai \\
menyetorkan hafalan satu halaman. \\
Tempat belajar tahsin dan kontak guru pendamping \\
dapat Anda lihat pada menu About. \\
Tips Menghafal Dengan Metode At-Taisir \\
Jumlah Halaman Mushaf Standar ada 604 halaman \\
Buat Program menghafal 1 Hari 1 Halaman \\
Alokasikan waktu menghafal sehari 2 jam \\
\hline
\end{tabular}

Gambar. 11. Menu Petunjuk

Menu petunjuk yang ditampilkan pada Gambar 11 berisi langkah-langkah secara garis besar tentang bagaimana menggunakan aplikasi At-Taisir, hal-hal penting apa saja yang harus diperhatikan sebelum mulai menghafal.

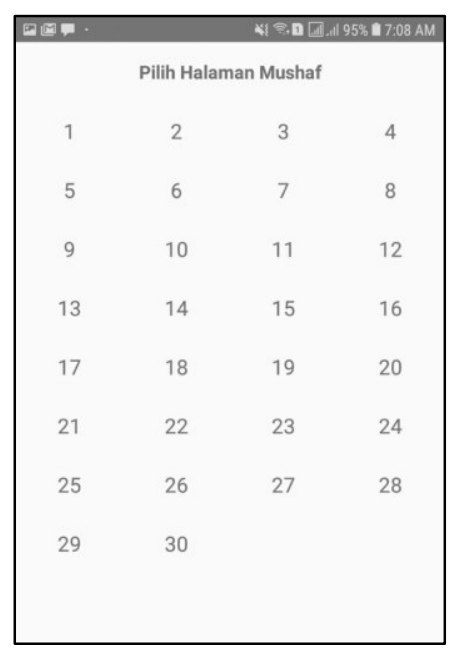

Gambar. 12. Menu Menghafal

Menu menghafal yang ditunjukkan oleh Gambar 12 menampilkan daftar halaman Al-Qur'an sebanyak 30 halaman sesuai dengan database yang telah dibuat untuk aplikasi ini dimulai dari juz 1 dan sebagian juz 2. Juz satu terdiri dari halaman 1 sampai halaman 21 sedangkan juz 2 terdiri dari halaman 22 sampai halaman 30. Setiap akan mulai menghafal, pengguna memilih nomor halaman terlebih dahulu yang nantinya akan membawa pengguna menuju proses berikutnya. Aplikasi ini didesain secara dinamis jadi ketika ingin menambahkan juz 3 misalnya, maka data-data yang dibutuhkan tinggal dimasukkan pada database kemudian akan tampil pada halaman ini. Sehingga total halaman yang ada jika ditambahkan juz 3 sebanyak 61 halaman. Begitu juga ketika akan ditambahakan hingga juz 30 Al-Qur'an, maka total nomor halaman yang akan tampil pada halaman ini sebanyak 604 nomor halaman Al-Qur'an.

Setelah memilih nomor halaman pada menu menghafal, pengguna secara otomatis akan dibawa menuju halaman Al-Qur'an sesuai nomor halaman yang dipilih sebelumnya. Halaman Al-Qur'an pada Gambar 13 menampilkan teks Al-Qur'an, terjemahan ayat dan audio Al-Qur'an. Jumlah ayat yang ditampilkan per halamannya berbeda-beda sesuai dengan jumlah ayat per halaman dalam Al-Qur'an pojok standar. Ketika ingin mendengarkan bacaan Al-Qur'an maka pengguna dapat menekan tombol play murottal. Terdapat fitur status hafalan pada halaman menghafal untuk menandai halaman yang sudah dihafalkan dan belum dihafalkan. Ketika sudah selesai menghafal dan yakin bahwa hafalan yang dihafalkan sudah sempurna, pengguna harus mengganti status hafalan dari belum hafal menjadi sudah hafal. Sebagai bentuk kehati-hatian dan mengurangi terjadinya kesalahan, terdapat notifikasi untuk meyakinkan pengguna apakah yakin sudah hafal atau masih ragu. 


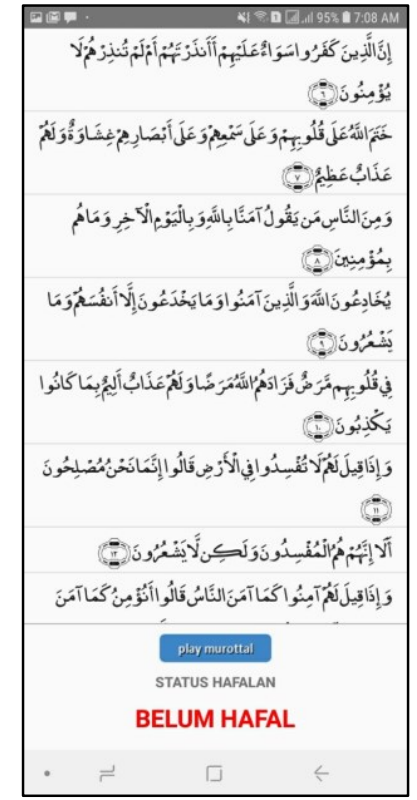

Gambar. 13. Halaman Al-Qur'an

\begin{tabular}{|cccc|}
\hline \multicolumn{4}{|c|}{ Pilih Halaman Mushaf } \\
\hline 1 & 2 & 3 & 4 \\
5 & 6 & 7 & 8 \\
9 & 10 & 11 & 12 \\
13 & 14 & 15 & 16 \\
17 & 18 & 19 & 20 \\
21 & 22 & 23 & 24 \\
25 & 26 & 27 & 28 \\
29 & 30 & & \\
\hline
\end{tabular}

Gambar. 14. Menu Murajaah

Menu murajaah pada Gambar 14 menampilkan hal yang sama layaknya menu menghafal. Pengguna memilih secara berurutan halaman yang tersedia dari halaman 1 sampai halaman 30 sesuai dengan hafalan yang ingin di-murajaah. Sebelum melakukan aktivitas murajaah harus dipastikan terlebih dahulu pengguna sudah memiliki pendamping yang akan menyimak hafalan yang akan di-murajaah atau disetorkan. Sama halnya dengan menu Menghafal, tampilan menu Muraja'ah ini juga didesain dinamis. Ketika ingin menambahkan halaman Al-Qur'an sebanyak 30 juz maka tinggal dimasukkan data-data Al-Qur'annya di database. Data inti halaman Muraja'ah adalah atribut awal_ayat, sebab potongan awal ayat inilah yang akan ditampilkan pada halaman Muraja'ah. Potongan awal ayat yang ditampilkan tidak diacak tetai sudah tersusun secara berurutan sesuai tampilan ayat Al-Qur'an.
Setelah memilih halaman yang ingin di-murajaah pengguna selanjutnya akan dibawa menuju halaman murajaah seperti pada Gambar 15. Halaman murajaah menampilkan potongan awal ayat tiap halaman. Potongan awal ayat ini diletakkan sesuai posisi halamannya di dalam Al-Qur'an pojok standar apakah disebelah kiri atau sebelah kanan. Hal ini berguna bagi pengguna untuk mengingat denah halaman Al-Qur'an agar hafalan yang dihafalkan semakin kuat. Terdapat fitur predikat pada halaman murajaah ini yang akan digunakan sebagai bahan evaluasi hafalan agar lebih baik dari waktu ke waktu. Ketika akan menyetorkan hafalan, pengguna meminta guru pendamping menyimak hafalan terlebih dahulu. Setelah selesai pengguna menunjukkan halaman Murajaah kepada guru pendamping dan meminta guru pendamping memilih predikat yang sesuai dengan kualitas hafalan yang sudah disetorkan. Predikat ini bersifat permanen artinya tidak dapat diubah kembali setelah diisi sama halnya dengan status hafalan yang juga bersifat permanen.

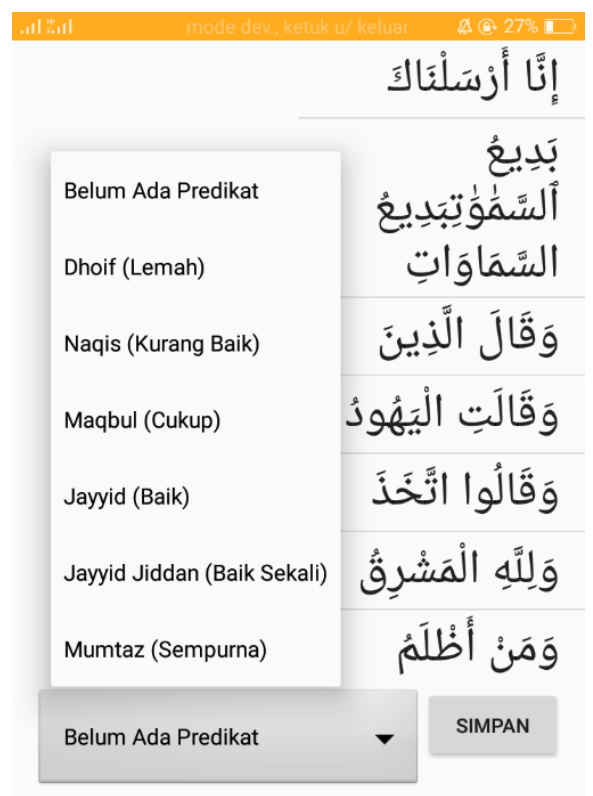

Gambar. 15. Halaman Murajaah

Menu about pada Gambar 16 menampilkan nomor kontak yang dapat dihubungi terkait aplikasi dan informasi guru tahsin sekaligus guru pendamping selama proses menghafal.

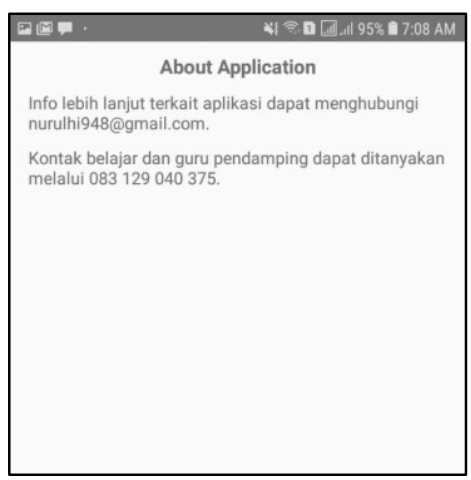

Gambar. 16. Halaman About 


\section{Pengujian Aplikasi dengan Black Box}

Metode pengujian black box ini digunakan untuk menguji fungsi-fungsi di dalam aplikasi At-Taisir. Pengujian metode black box ini fokus mengeksekusi unit atau modul apakah sudah sesuai dengan apa yang diinginkan[10]. Tabel I menunjukkan penjabaran fungsifungsi di dalam Aplikasi At-Taisir yang akan diuji menggunakan metode black box.

TABLE I. PENGUJIAN BLACK BOX

\begin{tabular}{|c|c|c|c|}
\hline $\begin{array}{l}\text { Skenario } \\
\text { Pengujian }\end{array}$ & $\begin{array}{l}\text { Hasil yang } \\
\text { diharapkan }\end{array}$ & $\begin{array}{c}\text { Hasil } \\
\text { Pengujian }\end{array}$ & Kesimpulan \\
\hline $\begin{array}{l}\text { Tampilan } \\
\text { Awal }\end{array}$ & $\begin{array}{l}\text { Menampilkan empat } \\
\text { menu (petunjuk, } \\
\text { menghafal, murajaah, } \\
\text { dan about) }\end{array}$ & Sesuai & Valid \\
\hline $\begin{array}{l}\text { Menu } \\
\text { Petunjuk }\end{array}$ & $\begin{array}{l}\text { Menampilkan } \\
\text { deskripsi petunjuk dan } \\
\text { tips menghafal }\end{array}$ & Sesuai & Valid \\
\hline \multirow[t]{2}{*}{$\begin{array}{l}\text { Menu } \\
\text { Menghafal }\end{array}$} & $\begin{array}{l}\text { Menampilkan } \\
\text { halaman Al-Qur'an } \\
\text { dalam bentuk angka } \\
1-30\end{array}$ & Sesuai & Valid \\
\hline & $\begin{array}{l}\text { Menampilkan } \\
\text { halaman Al-Qur'an } \\
\text { dalam bentuk ayat dan } \\
\text { terjemahan sekaligus } \\
\text { audio Al-Qur'an. }\end{array}$ & Sesuai & Valid \\
\hline $\begin{array}{l}\text { Fitur } \\
\text { Status } \\
\text { Hafalan }\end{array}$ & $\begin{array}{l}\text { Dapat menyimpan } \\
\text { status hafalan secara } \\
\text { permanen }\end{array}$ & Sesuai & Valid \\
\hline \multirow[t]{3}{*}{$\begin{array}{l}\text { Menu } \\
\text { Murajah }\end{array}$} & $\begin{array}{l}\text { Menampilkan } \\
\text { halaman Al-Qur'an } \\
\text { dalam bentuk angka } \\
1-30\end{array}$ & Sesuai & Valid \\
\hline & $\begin{array}{l}\text { Menampilkan } \\
\text { halaman Al-Qur'an } \\
\text { dalam bentuk kolom } \\
\text { kiri dan kanan. }\end{array}$ & Sesuai & Valid \\
\hline & $\begin{array}{l}\text { Menampilkan } \\
\text { potongan awal tiap } \\
\text { ayat Al-Qur'an per } \\
\text { halaman. }\end{array}$ & Sesuai & Valid \\
\hline $\begin{array}{l}\text { Fitur } \\
\text { Predikat }\end{array}$ & $\begin{array}{l}\text { Dapat menyimpan } \\
\text { predikat hafalan } \\
\text { secara permanen }\end{array}$ & Sesuai & Valid \\
\hline $\begin{array}{l}\text { Menu } \\
\text { About }\end{array}$ & $\begin{array}{l}\text { Menampilkan kontak } \\
\text { person }\end{array}$ & Sesuai & Valid \\
\hline
\end{tabular}

\section{E. Pengujian Aplikasi dengan MOS}

Pengujian MOS[11] dilakukan dengan pengisian kuesioner untuk 35 orang masyarakat umum yang belum menghafal dan sedang menghafal Al-Qur'an. Kuesioner yang dibagikan berisi beberapa pernyataan terkait aplikasi seperti pada Tabel II yang dibuat untuk kemudian dicari nilai rata-rata setiap poinnya sehingga didapatkan hasil berupa persentase manfaat dari aplikasi.

Jawaban yang digunakan pada tabel ada 5 pilihan yaitu Sangat Tidak Setuju (STS), Tidak Setuju (TS), Kurang Setuju (KS), Setuju (S), dan Sangat Setuju (SS). Sedangkan pernyataan yang diajukan yaitu:

1. Aplikasi mudah digunakan.

2. Tampilan dan desain aplikasi menarik.
3. Menu atau fitur aplikasi mudah dioperasikan.

4. Aplikasi bermanfaat untuk menghafal Al-Qur'an per halaman.

5. Menggunakan aplikasi ini untuk menghafal Al-Qur'an lebih praktis dibanding menggunakan metode At-Taisir secara manual.

6. Fitur tampilan dan langkah menghafal pada aplikasi sudah sesuai dengan metode At-Taisir.

TABLE II. KUESIONER PENGUJIAN MOS

\begin{tabular}{|c|c|c|c|c|c|c|}
\hline \multirow{2}{*}{ No. } & \multirow{2}{*}{ Pernyataan } & \multicolumn{5}{|c|}{ Jawaban } \\
\cline { 4 - 7 } & & STS & TS & KS & S & SS \\
\hline 1. & P1 & & & & 19 & 16 \\
\hline 2. & P2 & & & 9 & 21 & 5 \\
\hline 3. & P3 & & & 3 & 17 & 15 \\
\hline 4. & P4 & & & & 9 & 26 \\
\hline 5. & P5 & & & 1 & 20 & 14 \\
\hline 6. & P6 & & & 4 & 28 & 3 \\
\hline \multicolumn{2}{|l|}{ Jumlah Responden } & & \multicolumn{5}{|c}{35 orang } \\
\hline
\end{tabular}

Sesuai dengan hasil pengisian kuesioner oleh 35 orang responden tersebut selanjutnya dilakukan proses perhitungan rata-rata skor tiap pernyataan. Adapun untuk mendapatkan nilai persentase dari poin yang diteliti dilakukan dengan rumus pada Tabel III sehingga nilai persentase keberhasilan pengujian aplikasi dengan MOS yang didapatkan adalah $85.9 \%$.

TABLE III. HASIL PENGUJIAN MOS

\begin{tabular}{|c|c|c|c|}
\hline No. & Pernyataan & Skor MOS & Skor Maksimal \\
\hline 1. & P1 & 4.46 & 5 \\
\hline 2. & P2 & 3.88 & 5 \\
\hline 3. & P3 & 4.34 & 5 \\
\hline 4. & P4 & 4.74 & 5 \\
\hline 5. & P5 & 4.37 & 5 \\
\hline 6. & P6 & 3.97 & 5 \\
\hline \multicolumn{2}{|c|}{ Total Skor } & $\mathbf{2 5 . 7 6}$ & $\mathbf{3 0}$ \\
\hline \multicolumn{2}{r|}{\begin{tabular}{c} 
Persentase \\
\multicolumn{2}{r|}{ Pengujian MOS }
\end{tabular}} & $A=\frac{B}{C} \times 100 \% \frac{25.76}{30} \times 100 \%=85.9 \%$ \\
\hline
\end{tabular}

Hasil dari perhitungan rata-rata tiap jawaban dapat dibuatkan grafik seperti yang terlihat pada Gambar 17. Berdasarkan pengujian kuesioner yang dilakukan, pembangunan aplikasi ini memiliki jawaban tertinggi yaitu setuju dengan rata-rata sebanyak $54 \%$, jawaban sangat setuju dengan rata-rata sebanyak $38 \%$ dan jawaban kurang setuju sebanyak $8 \%$. 


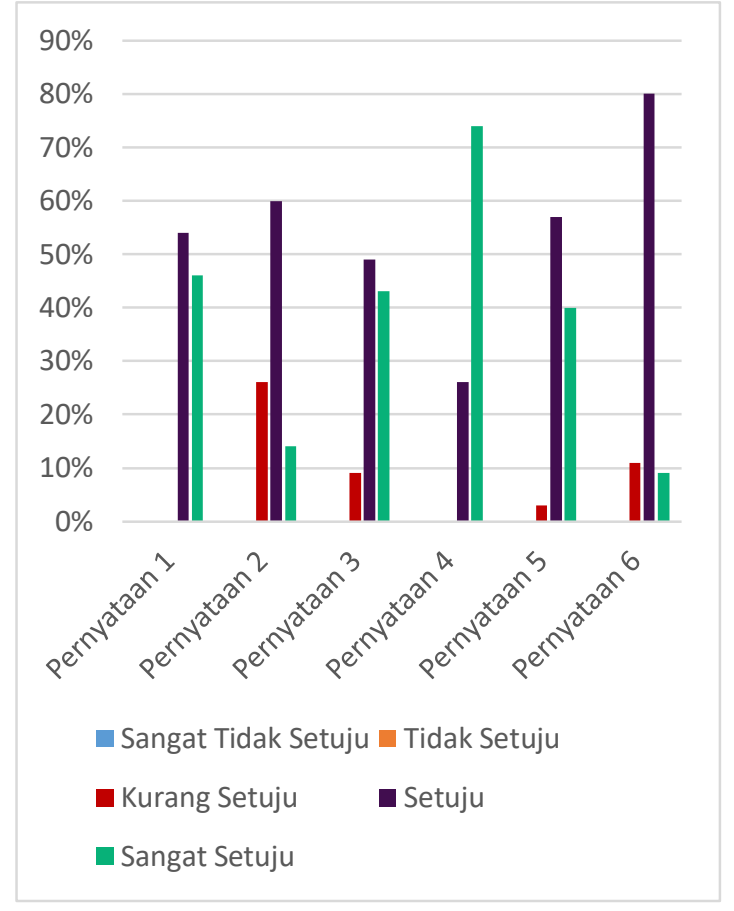

Gambar. 17. Grafik Persentase Hasil Pengujian MOS

\section{KESIMPULAN DAN SARAN}

Berdasarkan perancangan dan pembangunan aplikasi bantu hafal Al-Qur'an metode At-Taisir berbasis android ini maka dapat ditarik beberapa kesimpulan diantaranya:

1. Aplikasi At-Taisir yang sudah dibuat dapat menjadi alat bantu untuk memenuhi kebutuhan pengguna, khususnya yang ingin menghafalkan Al-Qur'an per halaman dan menggunakan metode At-Taisir.

2. Aplikasi bergerak yang dibangun mudah digunakan dan dapat dipahami oleh pengguna sesuai dengan hasil pengujian kuesioner $M O S$ dimana poin kemudahan ini responden menjawab setuju sebanyak 54\% dan menjawab sangat setuju sebanyak $46 \%$.

3. Hasil pengujian $M O S$ menunjukkan skor paling rendah terdapat pada pernyataan poin 2 yang berkaitan dengan tampilan dan desain aplikasi sehingga bisa diketahui bahwa pengguna membutuhkan aplikasi bantu hafal Al-Qur'an yang memiliki tampilan dan desain yang menarik.
4. Pengujian black box yang sudah dilakukan menunjukkan hasil bahwa semua fungsi berjalan sesuai dengan apa yang diharapkan

Untuk mengembangkan aplikasi lebih lanjut disarankan untuk menambah database Al-Qur'an menjadi 30 juz agar pengguna dapat menghafal Al-Qur'an secara berkelanjutan.

\section{DAFTAR PUSTAKA}

[1] Akhyartv, "Hari Al-Qur'an Muslim Zaman Now Hafal 30 Juz," Bekasi, 2018.

[2] D. Wijaya, "Perancangan Aplikasi Murojaah Al-Qur'an Sebagai Media Untuk Membantu Menghafal Al-Qur'an Berbasis Android," 2014.

[3] I. Afrianto, "Pembangunan Aplikasi Bantu Dalam Menghafal Al-Qur'an Berbasis Android," J. Ilm. Komput. dan Inform., vol. 2, pp. 1-8, 2013.

[4] L. Lubis, "Rancang Bangun Aplikasi Media Pembelajaran Tahfidz Al-Qur'an Berbasis Android," 2015.

[5] A. Qosim, Hapal Al-Qur'an Dalam Sebulan. Solo: Qiblat Press, 2008.

[6] A. Hidayat, Muslim Zaman Now Metode At-Taisir Hafal Al-Qur'an 30 Hari. Bekasi: Quantum Akhyar Institute, 2018.

[7] N. Safaat, Pemrograman Aplikasi Mobile Smartphone dan Tablet PC berbasis Android. Bandung: Informatika Bandung, 2011.

[8] R. A. S and M. Shalahuddin, Modul Pembelajaran Pemrograman Berorientasi Objek Dengan Bahasa Pemrograman $\mathrm{C}++$, PHP, dan Java. Bandung: Modula, 2010.

[9] E. A. K. Lestari, "Rancang Bangun Sistem Informasi Surat Perintah Perjalanan Dinas pada Sekretariat Daerah Provinsi Berbasis Web," Journal of Computer Science and Informatics Engineering (J-Cosine), vol. 2, p. 35, 2018.

[10] Fatta, Analisis Dan Perancangan Sistem Informasi Untuk Keunggulan Bersaing Perusahaan dan Organisasi Modern. Yogyakarta: Andi, 2007.

[11] S. Syaifullah, I. G. P. S. Wijaya, dan A. Y. Husodo, "Sistem Informasi Kepuasan Layanan Administrasi Akademik Berbasis IPA (Importance Performance Analysis) Studi Kasus Fakultas Teknik Universitas Mataram," Journal of Computer Science and Informatics Engineering (J-Cosine), vol. 2, no. 1, pp. 37-43, 2018. 